\title{
THE INFLUENCE OF PRODUCT QUALITY, FACILITY AND SERVICE QUALITY TOWARDS CUSTOMER SATISFACTION: CASE STUDY ON CUSTOMER SATISFACTION OF WARUNG APUNG MARITIM FOOD STALL, WEST SURABAYA
}

\author{
Setyowati Endang*, Purwogati Endah \\ Faculty of Economics, 17 Agustus 1945 Surabaya University, Indonesia \\ *Email: dra.endang@gmail.com
}

\begin{abstract}
ABSTRCT
Competition in the business world today is increasingly tight. It is also felt by such culinary business Warung Apung Maritim point. Many other attempts that have sprung up with the characteristics of each. So that the customer is satisfied and does not switch to another place, the company must determine the factors that influence customer satisfaction. Customer satisfaction can be created through the quality of products, facilities and quality of service. Specifically, this study discusses customer satisfaction Warung Apung Maritim. This study examined three independent variables are the quality of products, facilities and quality of service that can affect customer satisfaction. The purpose of this study was to determine the effect of three independent variables on customer satisfaction. This research was conducted by questionnaire to 100 subscribers Warung Apung Maritim point obtained by using purposive sampling. Then analysis of the data obtained in the by using quantitative and qualitative analysis. Quantitative analysis includes the validity and test reliability, multiple regression analysis, through regression coefficient (R2), F test and t test. Qualitative analysis is the interpretation of data obtained in the study and the results of data processing that has been carried out by giving a description and explanation. The results of this study indicate that all independent variables were tested positive and significant impact on customer satisfaction through $\mathrm{F}$ test and $\mathrm{t}$ test, whereas the number of Adjusted $\mathrm{R}$ Square of 0.311 showed $31,1 \%$ of the variation of customer satisfaction Warung Apung Maritim stalls which can be explained by the three independent variables, where the remaining $68.9 \%$ is explained by other factors outside the study. Of the three most dominant variable is the Quality of Product (X1) because it has the greatest value.
\end{abstract}

\section{KEY WORDS}

Quality product, facility, service quality, customer, satisfaction.

Along with the current development, there are many people who hard to get a job, so that starting a new business is a good choice. One of them is opening a restaurant. Starting a new restaurant is a business opportunity that has never receded but it continues to develop in accordance with more advanced age. It seems that there is no end to talk about this kind of business. We need to know that maybe starting a new restaurant is a very promising business opportunity. This kind of business also has risks like any other businesses if there is no innovation since it has to compete against other same businesses.

Thus it needs to learn any kind about starting a new business or things to consider before opening a new restaurant, so that it will go well as expected. Such a condition causes consumers have many alternatives to choose to use product of goods and service offered by producer. However, it is a form of threat for producer since the more goods and service offered; the more stringent the competition occurs in the business world. The increasingly fierce competition requires businesses to be able to maximize the performance of the company in order to compete in the marketplace. To overcome this condition, a company must have a strong marketing strategy in marketing their products and services so that they can withstand the competition. The conditions of fierce competition make costumers extremely vulnerable to change, so that each company is expected to follow the changing of desires of consumers continuously. Therefore, it results a change of mind, including in a marketing which is initially a transactional marketing turns into relationship marketing. 
The continued development of modern society is often associated with higher mobility of people and activities of hectic work which results in a growing number of workers who spend time outdoors. It leads them to always look for something that is both practical and instant in fulfilling their daily needs. One of them is by finding food and drinks outdoors. A number of career women spend their much time outside their home, so they find difficulty in carrying out activities as a housewife including preparing food for family. Therefore, they prefer to meet the needs of eating outside the home. Decision to eat outdoors has several functions, such as the availability of various menus so they can choose the one they want. In addition to meet the needs of eating, eating outdoors functions to search for place having a calm and comfortable condition to peace and comfort their condition after doing an exhausted work.

Each company generally wants to be successful in carrying out its efforts. Efforts to achieve the goals established by the company is, one of them, through marketing activities, that is a social process at which individual and group obtain what they need and want by creating deals, and freely exchanging valuable products with others.

Warung Apung Maritim food stall is one of restaurants selling processed fish and chicken foods. It locates at a housing area of Pondok Maritim Indah, West Surabaya. Coming up to its name, this restaurant provides fishing pond facility for visitors who want to catch fish which they will eat directly, so will result in good taste.

Warung Apung Maritim food stall is now experiencing fierce competition with similar restaurant like Lesehan Sekar Wangi dan Ikan Bakar Cimahi food stall. Today, Warung Apung Maritim food stall is also vigorously improving its management system in order to give more satisfaction to the customers. It also provides convenient facilities so that consumers do not feel bored while waiting for orders. The main key to win the competition is to offer satisfaction to customers through the delivery of quality products and services.

For that reason the company must continue to read what the customer needs in order to achieve a high level of customer satisfaction. Due to that fierce competition, company must understand what and how to manage its resources. If the customers feel satisfied, they will show the possibility to re-buy the same product. A satisfied customer will also be likely to provide a good reference for the product to others. But it will be different for customers who are not satisfied. Those customers would prefer to search for information of other products or services provide similar needs, and then they prefer to buy and use the products or services that are considered better to meet the satisfaction of their desires and leave the products or services before. They would also not recommend a product or service that is considered unable to meet their satisfaction to the people around them. That process will continue to repeat until consumers feel satisfied on product purchasing decisions. This research is expected to help businesses actor in the field of restaurant in selecting and determining whether this form of activity is quite effective in influencing consumer satisfaction.

According to that description, therefore the writer decided to conduct a study entitled "The Influence Of Product Quality, Facility, Quality Service Towards Customer Satisfaction" (Case Study on Customers of Warung Apung Maritim food stall, West Surabaya).

Problem Statement. According to the background previously explained, thus the problem statement of this study is as follow:

1. Does the quality of product, facility, service quality have simultaneous influence over the satisfaction of Warung Apung Maritim food stall's customers?

2. Does the quality of product, facility, service quality partially have influence over the satisfaction of Warung Apung Maritim food stall's customers?

3. Which one among the quality of product, facility, service quality has influence in a dominant manner over the the satisfaction of Warung Apung Maritim food stall's customers?

The Purpose of the Study. In accordance to the problem statement above, so that the objectives of the study are to:

1. Prove and analyze the relationship between the quality of product, facility, and services quality simultaneously has influence over the satisfaction of Warung Apung Maritim food stall's customers. 
2. Prove and analyze the relationship between the quality of product, facility, and services quality partially has influence over the satisfaction of Warung Apung Maritim food stall's customers.

3. Prove and analyze which one among the variable of product quality, facility, and services quality that has influence over the satisfaction of Warung Apung Maritim food stall's customers.

\section{LITERATURE REVIEW}

The Meaning of Marketing. The importance of marketing in a company is to reach the company's goal trying to place marketing as a central activity and guiding all of units produced towards achievement. Marketing is related to identify and fulfill the needs of people and community. According to Kotler and Amstrong (2001) marketing is a process of social and managerial resulting individual and group get what they need and want through the creating and exchanging of product and value with others. Fajar (2008) marketing is entire activities offering a product to fulfill the needs and desire of consumers. Marketing is a social process at which individual and group of people get what they need and want through creating, offering, and freely changing a valuable thing with the other side.

Wahjono (2009) said that marketing management is a planning and performing process of embodiment, pricing, promotion and distribution of goods, service and idea to create changing and organization. According to Mursid (2008) marketing is a process of goods or service shift from producer to customers. On the other hand it can be said that marketing is all of business activity related to the current supply of goods and service form producer to customers. Based on Lamb (2001) marketing is a process of planning and executing concept, price, promotion, and distribution a large number of idea, goods, and service to create an exchange which is able to satisfy the purpose of individual and organization.

Every company follows a type of concept or philosophy of company marketing as a basis of every activity in fulfilling the needs and desire. The development of marketing concept among others is as follow (Wahjono, 2009):

1. Concept of Production. Marketers holding on to this concept are oriented to the process. Production or operation (Internal) the assumption believed is that consumers will buy only cheap and easy to get products.

2. Concept of Product. Marketing considers that consumers have more desire only on products having superior quality, performance, or appearance.

3. Selling Concept. Selling-oriented concept (Internal) is at which marketers consider that consumers have to be affected or persuade (if needed) to increase selling.

4. Marketing Concept. Customer-oriented concept (external environment), it considers that consumers will buy only products that is able to fulfill the needs and desire as well as give pleasure.

Lupiyoadi and Hamdani (2006) explained that marketing mix is equipment for marketers that are comprised of any kinds of element of marketing program that need to be considered so that implementation of marketing strategic and positioning set can be successful. So that, element of service marketing mix is comprised of 7 matters, namely:

1. Product. Product is all of object concept or a process which gives a number of benefit values for consumers. Things in a product that need to be considered are consumers do not only buy physical form of the product but also buy benefit and value of it.

2. Price. Pricing is extremely significant in providing value for customer and influence the image of a product in a customer decision to buy. Price is also related to the income and also has influence over the supply. However, the most important thing is the decision of pricing has to be consistent with the entire marketing strategy.

3. Place. In term of service, place is a combination of location and decision of distribution channel. This is related to how the delivery of service to consumers is and where the strategic location is.

4. Promotion. Promotion is an activity to introduce a product, reassure the product's benefit to the target buyers aims they will buy product voluntarily. Thing needs to be 
considered in promotion is choosing promotion mix consisted of: advertisement, personal selling, selling promotion, and publicity.

5. People (Human Resource). In relation to the service marketing, people functions as service provider that influences the quality of service given. Decision in human resource means that it relates to selection, training, motivation, and management of human resource, to reach the best quality, employees have to be trained to realize the importance of their job, which is providing satisfaction to consumers to meet their needs.

6. Process. Process is a combination of all activities, commonly from procedure, work schedule, mechanism, activity and routine things at which services are produced and provided to consumers.

7. Customer Service. Service on the marketing of services rather is seen as the outcome from distribution and logistics activities, where the services provided to consumers in order to achieve satisfaction.

Definition of Service. Services are activities or benefits offered for sale, which is basically not real and does not result in any ownership. (Kotler and Armstrong, 2001). According to Arief (2007) the service is something intangible that act or performance offered by one party to the other party and does not lead to any transfer of ownership. In the production process, service can be both tied to a physical product and not.

Wahjono (2009) Services are all economic activity with output which is not only a product in a physical sense but also can be consumed and produced at the same time and provide added value as well as in principle is intangible for the first buyer. Kotler in Wahjono's book (2009) Services is any act or performance offered by one party to the other party which in principle is intangible and does not because the transfer of ownership, services production can be tied or not to a physical product.

Philip Kolter in Arief's book (2007) states that in general there are four characteristics of the service that can be identified as follows:

1. Intangibility. Intangible service cannot be seen, tasted, felt and heard before being purchased.

2. Inseparability. Service cannot be separated from the giver, either it is human being or machine. Services cannot be lined up on the shelves of sale and purchased by consumers whenever required.

3. Variability. Services are very multi-faceted, because it depends on who provide it and when and where it is available. Often the service buyers are aware of this great variation and discuss with the other before choosing one services provider.

4. Perishability. Services cannot be durable since it cannot be stored for sale or use in the future. The nature of services that are not durable is not a problem if there is a regular demand since the previous services can easily be prepared first. When the demand of services fluctuates, service companies will be faced with any kinds of difficult issue.

Quality of product. In essence, people buys a product is not just they want a have it. Consumers buy goods or services since it is used as a media to satisfy the needs and desires (Assauri, 2002). Or in other words someone buys a product not because of the physical product, but solely because of the benefits the product gives.

According to Kotler (1996) product is anything that can be offered to the market to get attention, purchased, used, or consumed to satisfy the desires or needs. Conceptually, product is a subjective understanding from producer of something which can be offered as an attempt to achieve organizational goals through fulfilling the needs and activities of consumers which is accordance with the competence and capacity of the organization as well as market purchasing power. Besides, product also can be defined as consumer perceptions described by a producer through the result of production. Products are considered to be important by consumers and used as a basis for decision making.

According to Assauri (2002), factors contained in a product are quality, features, options, style, brand names, packaging, size, line, product item, quarranties, and service. From those definitions it can be concluded that the product was not only in the form of 
tangible goods but it could be a service, so the product can provide a different satisfaction so that the company is required to be more creative and comprehensive view of the product produced. The quality of the products is affected by the factors that will determine the quality of goods that can meet the goal of increasing sales volume (Assauri, 2002).

Facility. Facilities are everything ease the consumers to use the services of a company. Facility is a physical resource before service is being offered to consumers (Kotler and Armstrong, 2001). Facilitiy is any kinds of thing which eases consumers in businesses engaged in services. So that, all the existing facilities, such as the condition of the facilities, fittings, interior and exterior design, as well as the cleanliness of the facility should be pay attention, particularly thing that is closely associated with what is perceived or obtained consumers directly. Indeed, customers have to be satisfied, because if they are not satisfied, they will leave the company and being a customer for competitors. This will make the decline in sales and in turn will decrease the company's revenue. Meanwhile, according to Kotler and Armstrong (in Tjiptono, 2004) facility is any kind of things in the form of physical equipment and provided by the sellers to support consumer convenience.

According to (Bahtiar, 2009) the design and layout of the facility services is closely related to the formation of customer perception. Some types of services, perception formed from the interaction between the customer and the facility has influence over the quality of services in the customer's eyes.

Service Quality. Service is an activity undertaken to meet the desires and needs of other parties. Moenir (1995) defines service as a fulfillment process through the activity of others. Service activities geared towards the implementation of services to meet the interests of individuals or community through appropriate ways and satisfy parties who are served. To make the service reaches the goal, so that the element of performer is extremely definitive. Performer is a person, agency or organization who responsible for the implementation of service (Bahtiar, 2009). According to Siagian (in Julita, 2001) the meaning of service in a general is a sense of fun that is given to others with easiness and meet all their needs. So that service is a form of the procedure given in an attempt to give pleasures to others, in this term is to the customer. Meanwhile, according to Philip Kotler, service implies every activity or the benefits provided by one party to another that is essentially intangible and does not result in the ownership of anything anyway (Kotler, 1996). Referring to the understanding of the meaning of the concept of service quality service quality and responsiveness is a reality of the services provided by the company. Quality of service should be started from the needs of customers and end on customer perception (Kotler in Wisnalmawati, 2005).

Parasuraman et. al (in Lupiyoadi, 2001) states that service quality is the hallmark characteristics or properties of a product or service that affects the ability to satisfy the needs of consumers. Quality of service can be determined by comparing the perceptions of consumers for services received by consumers expect real service to the attributes of the service of a company.

Parasuraman et. al (in Lupiyoadi, 2001) the company's success in providing quality service to its customers includes the five dimensions of service, namely:

1. Reliability, the ability to reliably and precisely deliver what it has promised.

2. Assurance or guarantees and certainty, includes knowledge and courtesy of employees and their ability to impress trust and confidence.

3. Tangibles, including physical facilities, equipment, and personnel performance.

4. Empathy, a level of care and individual attention given to customers.

5. Responsiveness, the desire of the staff to help customers and provide prompt service.

There are two main factors that affect the quality of service, that is, expected service and perceived service. If the services received or perceived is as expected, thus the quality of service is perceived as an ideal quality. Conversely, if the service received is lower than expected, and then quality of services is perceived to be poor. Therefore, good or not the quality of service depends on service providers' ability to meet the customer expectations consistently. 
According to Lupiyoadi (2001) quality needs to be understood and managed in all parts of the service organization. Service quality issues often arise in four aspects, namely:

1. Meeting services, is any direct interaction between employees and customers with physical facilities of service providers.

2. Design services, is the process passed by customers in order to obtain a service.

3. Productivity of services, is the relationship between the quantity and quality of goods / services produced by the quality of the resources used to produce goods or services.

4. Cultural and service organization, the quality of services can also be influenced by the organization's culture and way of organizing.

Consumer Satisfaction. Satisfaction is happy or disappointed feeling of someone arising from comparing the performance of perceived product (or result) against their expectations (Kotler and Armstrong, 2001). Customer satisfaction has become a central concept central in the theory and practice of marketing, and is one of the essential destination for business activity. Customer satisfaction contributes to a number of crucial aspects, such as the creation of customer loyalty, the enhance of company reputation, the reduce price elasticity, the reduce of future transaction costs, and the increase of efficiency and productivity of employees, (Tjiptono, 2004)

The word satisfaction was derived from the Latin "satis" (means good enough, adequate) and "facio" (performing or make). In a simple way, satisfaction can be defined as "efforts to comply with something" or "make something adequate". Basically, the purpose of a business is to create customers who are satisfied. The creation of customer satisfaction can provide several benefits, including the relationship between the company and its customers to be harmonious, provides a good basis for the re-purchase and creation of customer loyalty, and form a recommendation communication by word of mouth that is profitable for the company, Mowen and Minor (in Swastha, 2000).

There are several methods that can be used by each company to measure and monitor customer satisfaction and customer competitors. Kotler, et. al. (In Tjiptono, 2004) \{UT1\} identified four methods to measure customer satisfaction, namely:

1. Complaints and Feedback System. Each customer-oriented company needs to provide greater opportunities for its customers to submit suggestions, opinions and complaints. Media that can be used include suggestion boxes placed in strategic places (easily accessible or frequently passed by customers), providing comment cards (which can be filled directly or can be sent via email to the company), providing customer hot lines, and others. The information obtained through this method can provide new ideas and valuable input to the company, making it possible to respond quickly and responsive to any problems that arise. However since these methods tend to be passive, it is difficult to get a complete picture of customer satisfaction and dissatisfaction.

2. Customer Satisfaction Survey. Companies send a list of questions or phoned the last customer as a random sample and ask if they are very satisfied, satisfied, average, dissatisfied, or very dissatisfied with various aspects of corporate performance. They also ask the buyer's opinion about the performance of their competitors.

3. Ghost Shopping. Companies can pay people to act as potential buyers in order to report on their findings about the strengths and weaknesses they experience when buying the company's products or competitors' products.

4. Analyzing the Missing Customers. Companies should contact customers who stop buying or changing suppliers to learn why the reason. When companies lose customers, the company will conduct in-depth effort to study their failures. Important things to do is not only conducting an interview when customers stopped buying, but also it needs to pay attention customer loss rate which if it increases, clearly shows that the company failed to satisfy its customers. 


\section{RESEARCH FRAMEWORK}

A theoretical framework is as presented in literature reviews and previous research; it can be arranged in the following picture:

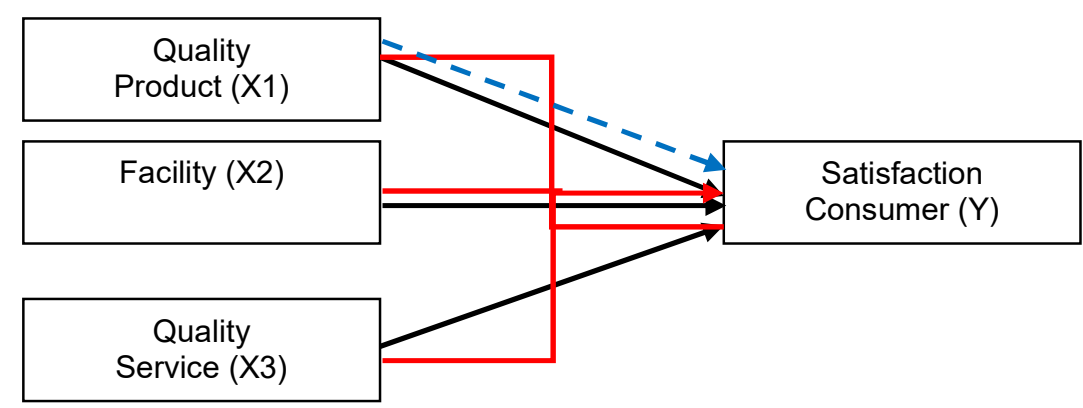

Description:

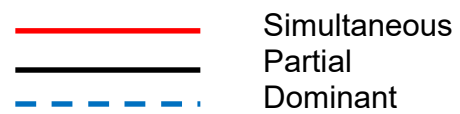

Source: Apriani, 2011 (having been improved by the writer).

Hypothesis. Hypothesis is a temporary answer towards research problem until it can be proven through collected data (Arikunto, 2005). Based on the problem statement and literature review, the hypothesis proposed in this study are:

$\mathrm{H} 1$ : Having been predicted that the quality of product, facility, service quality has simultaneous influence over the customer satisfaction of Warung Apung Maritim food stall, West Surabaya.

$\mathrm{H} 2$ : Having been predicted that the quality of product, facility, service quality has partial influence over the customer satisfaction of Warung Apung Maritim food stall, West Surabaya.

H3: Having been predicted that the quality of product has dominant satisfaction over the customer satisfaction of Warung Apung Maritim food stall, West Surabaya.

\section{METHODS OF RESEARCH}

Research Design. Research design becoming a model of a constellation of research for measurement of the influence of independent variables towards dependent variable includes the following explanation:

1. $\mathrm{X} 1$ is the quality of product that is positioned as independent variable.

2. $\mathrm{X} 2$ is facility which is also positioned as independent variable.

3. $\mathrm{X} 3$ is Service quality which is also positioned as independent variable.

4. $\mathrm{Y}$ is Consumer satisfaction positioned as dependent variable

Place and Location. This study was undertaken at Warung Apung food stall and Kolam Pancing Maritim fishing pond, West Surabaya. The object of the study is the customers of Warung Apung food stall and Kolam Pancing maritim fishing pond that have fulfilled criterion and been determined before. This research lasted for 2 months, started on December 2016 until January 2017.

Population. Population is a combination of all the elements in the form of events, things or people who have similar characteristics that became the center of attention of the researchers, because it is seen as a research universe (Ferdinand, 2006). In this study population are all consumers Maritime Floating point numbers are not known with certainty. Therefore, the samples were taken for this study.

Sample. The sample is a subset of the population, made up of some members of the population.

This subset is taken because in many cases there may investigate all members of the population, therefore, should establish a representative population called (Ferdinand, 2006). 
The guidelines used in determining the sample size, if the population is large and the number is not known, it is used formula (Sugiyono, 2009). For that reason, the number of sample used in this study is 100 respondents.

Definition of Operational. The operational definition is the definition given to a variable or construct by giving meaning, or specify clarity, or to provide an operational needed to measure the construct or variable (Sugiyono, 2010).

Definition of Operational of this study:

The Quality of product (X1). The ability of a product to perform its function, covering to durability, reliability, accuracy, ease of operation and repair, and another valuable atribute. (Kotler, 2005). The quality of product as an independent variable (x1) was measured by indicator:

Durability for instance:

- Food do not change its color and smell even it is stored for a long time.

Reliablity:

- Any kind of food served at Warung Apung Maritim food stall has delicious taste.

- Having employees who are able to process food and beverage.

Accuracy:

- Warung Apung Maritim food stall is having consistence quality and taste.

- Taste of food or beverage served there is good like its appearance.

Ease of operation and repair:

- Warung Apung Maritim food stall are opened for critic and suggestion from customer.

- Located in a strategic place.

Performance quality, for instance:

- Having good quality of food and beverage.

- Materials used to process food and beverage has good nutrient content.

Style, for instance:

- Having an interesting serving concept.

- Having neat and hygienic packaging.

Facility (X2). As an independent variable (X2), facility was measured by indicators:

Cleanliness, comfort, and completeness of Warung Apung Maritim food stall, among others:

1. Having clean and comfort place.

2. Completeness of additional element (worship place, toilet, parking area, washbasin, listening to radio or watching TV, and internet connection).

Tangible, for instance:
indicator:

Service Quality (X3). Service quality as an independent variable (X3) was measured by

- Additional supporting facility provided is clean and in a good condition.

- Security of parking area provided.

- Having a fishing pond.

Reliability, for instance:

- Having punctuality in serving food and beverage to customers.

- Accuracy of calculation owned by cashier when customers pay.

Responsiveness, for instance:

- Having speed ability to serve customers.

- Employees do not keep customers stand for a long time when there is no space.

Assurance, for examples:

- Always keeping food and beverage clean and fresh.

- Customers feel safety when they are in Warung Makan Apung Maritim food stall.

- Empathy.

- Having employees who can understand the special needs of customers.

- Politeness and friendliness of employees in providing service to customers. 
Customer Satisfaction. Customer Satisfaction as dependent variable was measured by indicator:

- Satisfaction on service

- Resulted product satisfaction

- Facility which is felt and enjoyed by consumers.

Source of Data. Data that was used to conduct this study are:

1. Primary Data. Primary data are data obtained directly from the original source (not through an intermediary medium), primary data produced in this study is the result of interviews or distributing questionnaires to customers who have come to Warung Apung Maritim food stall to obtain respondents' respond towards the attributes of the study to be tested.

2. Secondary Data. Secondary data that is available in the study came from the literature that supports the writing of research as well as derived from the relevant literature to the research, as the basis of understanding to the research object and to analyze them appropriately.

Data Collection Techniques. Data collection techniques in a scientific research intended to obtain the relevant materials and reliable technique of collecting data.

Data used in this study are:

1. Questionnaires:

Questionnaire is one of the methods of data collection which is performed by providing a list of questions to respondents, both opened and closed ended questions. Closed-ended question is measured by using scale with interval 1-4, namely extremely bad, bad, good, extremele good. Opened-ended question comprised of questions to explain respondent's identity. The use of scale 1-4 is to avoid respondent's answer that tend to choose average answer which will result in a grey area respond.

2. Literature Review:

Literature Review is the method of data collection which is done by reading books, magazines, literature, journals, reference related to this study and previous research related to the study that is being done.

\section{HYPOTHESIS TESTING TECHNIQUES}

$t$ test (partial test). This analysis is used to determine partially or per variable the influence of independent variables on the dependent variable.

Testing criterion of $t$ test is as follows:

1. If the significance level $<0.05$ then $\mathrm{Ho}$ is rejected and Ha accepted, it means that there is significance influence of independent variable towards dependent variable individually.

2. If the significance level> 0.05 then $\mathrm{Ho}$ is accepted and $\mathrm{Ha}$ is rejected, it means that there is no significance influence of individual variable towards dependent variable individually (Ghozali, 2006).

$f$ test. This test is done to see whether the model analyzed has the feasibility of the model has high feasibility level, at which variables used in the model is able to explain the phenomenon analyzed. In addition, testing is done to show whether all the independent variables included in the model have a simultaneous effect on the dependent variable. The research was done by looking at $\{U T 1\}$ Anova comparing Mean Square of regression and Mean Square of residual, so that the result is called $F$ count. If the $F$ count $>F$ table and if the significance level $<\alpha(0.05)$, thus independent variables simultaneously has influence over the dependent variable (Ghozali, 2006).

\section{DATA ANALYSIS TECHNIQUE}

Test validity. test validity is used to determine the validity of a stuffing draft. A draft is said to be valid if the questions able to reveal something that will be measured by the draft. Test validity is done by comparing the value of $r$ count (correlated item-total correlation) with 
the value of $r$ table. If the value of $r$ count $>r$ table and is positive then the question is said to be valid (Ghozali, 2005).

Test Reliability. Reliability is a tool to measure a questionnaire which is an indicator of a variable. A questionnaire is said to be reliable if someone's answers to questions are consistent or stable over time. SPSS software application gives facility to measure the reliability by statistical test of Cronbach Alpha $(\alpha)$. A variable is said to be reliable If provides value (a) 0.60 (Ghozali, 2005). Cronbach Alpha coefficients interpret the correlation between the scales made with all the scales of existing indicators with a confidence of constraint level. Indicators can be accepted if the coefficient between scale of existing and a confidence of constraint level is available. Indicators can be accepted if the alpha coefficient is above 0.60 . A variable is said to be reliable if the Cronbach Alpha value $>0.60$ (Ghozali, 2005).

Multiple Linear Regression. In an effort to answer the problem of this research, we use multiple linear regression. Multiple linear regression was used to analyze the influence of independent variables (the quality of product and brand image) towards the dependent variable (purchase decisions). Computation of linear regression is as follows (Wijaya et al., 2010):

$$
Y=a+b_{1} X_{1}+b_{2} X_{2}+b_{1} X_{3+} e
$$

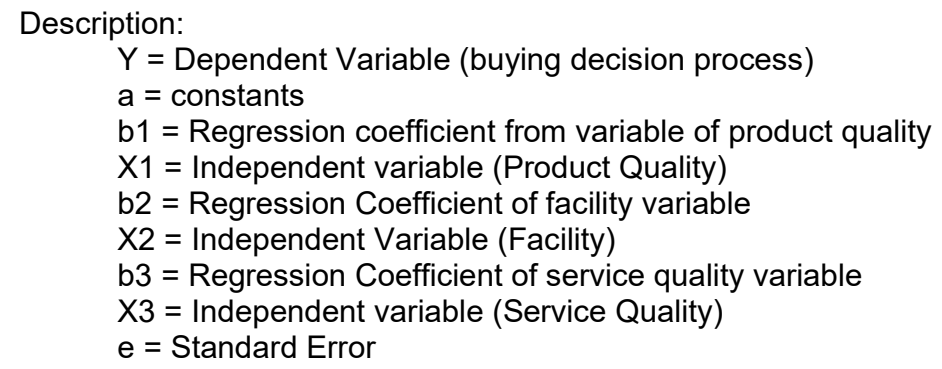

Coefficient of determination (R2). Coefficient of determination is used to describe how much ability of a model to explain the variations that occur in the dependent variable indicated by $\mathrm{R}$ Square in Model Summary generated by SPSS, at which the value of the coefficient determination is between 0 and 1 . If the value of $R 2$ is getting very close to 1 , then the regression model is considered to be better as independent variables used in this study could explain the dependent variable. This research is based on the value of Adjusted $R$ Square or coefficient of determination that has been adjusted, because if it uses $R$ Square value, it will lead to a bias that can increase $R 2$ if there is addition of independent variable. In contrast to $R$ Square, the value of Adjusted $R$ Square will not lead to bias because the value of $R$ Square can go up or down if an independent variable was added in the model (Ghozali, 2006).

Correlation Coefficient $(R)$. It is a measurement of relationship close lines between dependent variable with all the independent variables in a together manner. Multiple correlation coefficients can be seen in the Table of $\mathrm{R}$ Summary Model (the result of output from data processing). $R$ is the relationship between the dependent variable and independent variable.

With the testing criteria as follows:

1. If $R=-1$ or close to -1 , then the relationship between the two variables are strong or perfect negative, it means that the variable is tight or strong and not clockwise or counter.

2. If $R=1$ or close to 1 , then the relationship between the two variables is very strong or perfect positive, it means that the correlation between the two variables is close or strong and are unidirectional.

3. If $R=0$ or close to 0 , then the relationship between the two variables is very weak or there is no relationship at all. 


\section{TEST PREREQUISITES OF ANALYSIS}

Test Validity. Measuring instrument will be considered to be valid if the level of significance value obtained from each question of variable is $<0.05$.

Table 1 - Test Validity

\begin{tabular}{|c|c|c|c|c|c|}
\hline Variable & Question & Correlation Coefficient & $r$ table & Sig & Conclusion \\
\hline \multirow{11}{*}{$\begin{array}{c}\text { Quality } \\
\text { Product } \\
\text { (X1) }\end{array}$} & $\mathrm{X} 1.1$ & 0,566 & 1,945 & 0,000 & Valid \\
\hline & $\mathrm{X} 1.2$ & 0,603 & 1,945 & 0,000 & Valid \\
\hline & $\mathrm{X} 1.3$ & 0,516 & 1,945 & 0,000 & Valid \\
\hline & $\mathrm{X} 1.4$ & 0,499 & 1,945 & 0,000 & Valid \\
\hline & $\mathrm{X} 1.5$ & 0,554 & 1,945 & 0,000 & Valid \\
\hline & $\mathrm{X} 1.6$ & 0,347 & 1,945 & 0,000 & Valid \\
\hline & $\mathrm{X} 1.7$ & 0,264 & 1,945 & 0,000 & Valid \\
\hline & $\mathrm{X} 1.8$ & 0,584 & 1,945 & 0,000 & Valid \\
\hline & $\mathrm{X} 1.9$ & 0,567 & 1,945 & 0,000 & Valid \\
\hline & $\mathrm{X} 1.10$ & 0,497 & 1,945 & 0,000 & Valid \\
\hline & $\mathrm{X} 1.11$ & 0,556 & 1,945 & 0,000 & Valid \\
\hline \multirow{2}{*}{$\begin{array}{l}\text { Facility } \\
(\mathrm{X} 2)\end{array}$} & $\mathrm{X} 2.1$ & 0,873 & 1,945 & 0,000 & Valid \\
\hline & $\mathrm{X} 2.2$ & 0,533 & 1,945 & 0,000 & Valid \\
\hline \multirow{11}{*}{$\begin{array}{c}\text { Quality } \\
\text { Service } \\
\text { (X3) }\end{array}$} & $\mathrm{X} 3.1$ & 0,327 & 1,945 & 0,000 & Valid \\
\hline & $\mathrm{X} 3.2$ & 0,507 & 1,945 & 0,000 & Valid \\
\hline & $\mathrm{X} 3.3$ & 0,508 & 1,945 & 0,000 & Valid \\
\hline & $\mathrm{X} 3.4$ & 0,683 & 1,945 & 0,000 & Valid \\
\hline & $\mathrm{X} 3.5$ & 0,724 & 1,945 & 0,000 & Valid \\
\hline & $\mathrm{X} 3.6$ & 0,741 & 1,945 & 0,000 & Valid \\
\hline & $\mathrm{X} 3.7$ & 0,668 & 1,945 & 0,000 & Valid \\
\hline & $\mathrm{X} 3.8$ & 0,696 & 1,945 & 0,000 & Valid \\
\hline & X3.9 & 0,677 & 1,945 & 0,000 & Valid \\
\hline & $\mathrm{X} 3.10$ & 0,624 & 1,945 & 0,000 & Valid \\
\hline & $\mathrm{X} 3.11$ & 0,695 & 1,945 & 0,000 & Valid \\
\hline \multirow{3}{*}{$\begin{array}{c}\text { Satisfaction } \\
\text { Consumer }(\mathrm{Y})\end{array}$} & Y.1 & 0,881 & 1,945 & 0,000 & Valid \\
\hline & Y.2 & 0,849 & 1,945 & 0,000 & Valid \\
\hline & Y.3 & 0,883 & 1,945 & 0,000 & Valid \\
\hline
\end{tabular}

Source: Respondents' answer that was then processed by the researcher.

Table 1 indicates that the results of test validity from all independent variables or dependent variable is valid, because the significance value $<0.05$ and a correlation coefficient ( $r$ count) is greater than the value of $r$ table, so it is stated that all of research variables is stated to be valid.

Test Reliability. Reliability test is a tool to measure a questionnaire which is an indicator of the variables that can provide fixed information when it is used repeatedly. Test reliability of this research uses the formula of Cranach's Alpha.

Table 2 - Test Reliability of Research Variable

\begin{tabular}{|c|c|c|}
\hline Variable & Alpha & Conclusion \\
\hline The Quality of product (X1) & 0,719 & Reliable \\
\hline Facility (X2) & 0,766 & Reliable \\
\hline Service Quality (X3) & 0,754 & Reliable \\
\hline Customer Satisfaction & 0,853 & Reliable \\
\hline
\end{tabular}

Source: Respondents' answer that was then processed by the researcher.

Table 2 indicates that those four variables show that all variables have Alpha coefficients are above 0.60 so it can be said that all measurement concept from each variable of questionnaire is reliable and can be used for further processing.

Multiple Linear Regression. Multiple Linear Regression aims to observe how the influence of each of independent variable of the quality of product (X1), facilities (x2), Service Quality (X3) towards dependent variable of Customer Satisfaction (Y) 
Table 3 - The Result of Multiple Linear Regression

Coefficients $^{a}$

\begin{tabular}{|c|c|c|c|c|c|c|}
\hline \multirow[b]{2}{*}{ Mod } & & \multicolumn{2}{|c|}{ Unstandardized Coefficients } & \multirow{2}{*}{$\begin{array}{c}\text { Standardized } \\
\text { Coefficients }\end{array}$} & \multirow[b]{2}{*}{$\mathrm{t}$} & \multirow[b]{2}{*}{ Sig. } \\
\hline & & B & Std. Error & & & \\
\hline \multirow[t]{4}{*}{1} & (Constant) & 3.835 & 2.250 & & -1.704 & .092 \\
\hline & Kualitas Produk & .162 & .051 & .297 & 3.186 & .002 \\
\hline & Fasilitas & .064 & .247 & .224 & 2.611 & .001 \\
\hline & Kualitas Pelayanan & .106 & .034 & .287 & 3.108 & .002 \\
\hline
\end{tabular}

a. Dependent Variable: Kepuasan Konsumen

Source: Respondents' answer that was then processed by the researcher.

From the table it can be used to construct an equation model of multiple linear regression as follows:

$$
Y=3.835+0,162 \times 1+0,064 \times 2+0,106 \times 3
$$

Interpretation of the regression model above is as follows:

Variable of the quality of product has a value of 0.162 . This means that if the variable of product quality up one unit, customer satisfaction will also increase by 0.162 units, if other factors remain. In addition, the higher the quality of product, the higher the customer satisfaction. The positive sign indicates that the quality of product has positive influence towards customer satisfaction.

The value of facility variable is 0.064 , it means that if variable of facility up one unit, then customer satisfaction will increase by 0,064 units, other factors remain. It indicates positive value which means the level of customer satisfaction is high.

The value of service quality variable is 0.106 , it means that if the variable of service quality up one unit, then customer satisfaction will increase by 0.106 and other factors remain. It indicates positive value which means the better the quality of service, the higher the satisfaction of customer. Therefore, if the entire variable's value increases one unit, it will increase the value of customer satisfaction from 4167 to 3.835 .

Correlation Coefficient $(R)$ and coefficient of determination (R2). Coefficient $R$ shows the degree of closeness of the relationship between independent variables and dependent variable, while the coefficient of determination is an accuracy analytical tool in multiple linear regressions.

Table 4 - Correlation Coefficient and Coefficient of Determination

Model Summary

\begin{tabular}{|l|l|l|r|r|}
\hline Model & $\mathrm{R}$ & $\mathrm{R}$ Square & $\begin{array}{c}\text { Adjusted R } \\
\text { Square }\end{array}$ & $\begin{array}{c}\text { Std. Error of } \\
\text { the Estimate }\end{array}$ \\
\hline 1 & $.558^{\mathrm{a}}$ & .311 & .289 & 1.105 \\
\hline
\end{tabular}

a. Predictors: (Constant), Kualitas Pelayanan, Fasilitas, Kualitas Produk

At table 4, it can be seen the value of the correlation coefficient $(R)$ indicates how close the relationship between independent variables and dependent variable, the value of correlation coefficient was 0.558 . The value indicates that the relationship between variable of the quality of product (X1), Facilities (X2), Service quality (X3) and consumer satisfaction $(Y)$ is truly close or very strong as it approaches a value of 1. 
The value of coefficient of determination or $\mathrm{R} 2$ is used to measure how far the model's ability to explain dependent variations or dependent variable $(\mathrm{Y})$. The results of calculation of SPSS acquired the coefficient of determination (R2) amounted to 0.311, this shows that $31.1 \%$ of the variation in the variable of customer satisfaction explained by variable of the quality of product, facilities, and services quality. While the remaining, $68.9 \%$, influenced by other variables not included in this study.

\section{HYPOTHESIS TESTING}

Partial test (t test). This analysis is used to determine partially the influence of independent variables towards dependent variable per variable.

Testing criterion of $\mathrm{t}$ test is as follows:

1. If the significance level $<0.05$ then $\mathrm{Ho}$ is rejected and Ha accepted, it means that there is significance influence of individual variable towards dependent variable individually.

2. If the significance level> 0.05 then $\mathrm{Ho}$ is accepted and $\mathrm{Ha}$ is rejected, it means that there is no significance influence of independent variable towards dependent variable individually.

Table 5 - The Result of $t$ Test

Coefficients $^{a}$

\begin{tabular}{|c|c|c|c|c|c|c|}
\hline \multirow[b]{2}{*}{ Mod } & & \multicolumn{2}{|c|}{ Unstandardized Coefficients } & \multirow{2}{*}{$\begin{array}{c}\begin{array}{c}\text { Standardized } \\
\text { Coefficients }\end{array} \\
\text { Beta } \\
\end{array}$} & \multirow[b]{2}{*}{$t$} & \multirow[b]{2}{*}{ Sig. } \\
\hline & & $B$ & Std. Error & & & \\
\hline \multirow[t]{4}{*}{1} & (Constant) & 3.835 & 2.250 & & -1.704 & .092 \\
\hline & Kualitas Produk & .162 & .051 & .297 & 3.186 & .002 \\
\hline & Fasilitas & .064 & .247 & .224 & 2.611 & .001 \\
\hline & Kualitas Pelayanan & .106 & .034 & .287 & 3.108 & .002 \\
\hline
\end{tabular}

a. Dependent Variable: Kepuasan Konsumen

Source: Respondents' answer that was then processed by the researcher.

Partial Test between Variable of The quality of Product (X1) towards Customer Satisfaction Variable ( $Y$ ). Based on the results of research data processing, having been obtained the significance of 0.002 which means that if the value is less than $0.05 \mathrm{Ha}$ received, so the conclusion is variable of the quality of Product (X1) has positive significant influence over the Customer Satisfaction $(Y)$.

Partial Test between Variable of Facility (X2) towards Customer Satisfaction Variable (Y). Based on the results of processing data, having been obtained the significance of 0.001 which means that the value is less than 0.05 , so that $\mathrm{Ha}$ is received, thus the conclusion is variable of facility $(X 2)$ has positive significant influence on the customer satisfaction $(Y)$.

Partial Test between Service Qualities (X3) towards Customer Satisfaction Variable (Y). Based on the results of processing data, having been obtained the significance by 0.002 which means that the value is less than 0.05 , so that $\mathrm{Ha}$ is received, thus the conclusion is variable of service quality (X3) has positive significant influence towards customer satisfaction $(Y)$.

Simultaneous Test (test F). Simultaneous test ( $F$ test) shows that all independent variables consisting of the quality of Product (X1), facility (X2), Service Quality (X3) simultaneously has influence over the dependent variable of Consumer Satisfaction $(Y)$.

Table 6 - The Result of $F$ test calculation

\begin{tabular}{|c|c|c|}
\hline F count & F table & Conclusion \\
\hline 14,432 & 2,31 & F count $>\mathrm{f}$ table \\
\hline
\end{tabular}

Source: Respondents' answer that was then processed by the researcher. 
Since $\mathrm{F}$ count $>\mathrm{F}$ table, that is, $14.432>2.31$, so that Ho was rejected at the level of significance $5 \%$ so that it can be concluded that independent variable (Product quality, facility, service quality) has simultaneously significant influence towards $Y$ dependent variable (Consumer satisfaction at Warung Apung Maritim).

\section{DISCUSSION OF RESULTS}

Partial Influence. Test of partial influence of each impendent variable towards dependent variable was conducted by using $t$ test.

1. The Influence of Product Quality on Customer Satisfaction:

Variable of the quality of product partially has significant influence over the customer satisfaction. This can be known from its significance by 0.002 which means less than 0.05 . The results of this study prove that the quality of product has positive or significant influence over the customer satisfaction, at which the increase of the quality of product will result in an increased of customer satisfaction. The result indicates that the hypothesis "Allegedly there is an influence of the quality of product towards customer satisfaction of Warung Apung Maritim food stalls" is accepted.

2. The Influence of Facility towards Customer Satisfaction:

Variable of Facility partially has significant influence on customer satisfaction. It is known from the significance of 0.001 which means less than 0.05 . The results of this study prove that the facility has positive or significant influence towards customer satisfaction, at which the increase of facility will result in an increase of customer satisfaction. The result indicates that the hypothesis "Allegedly there is an influence of the quality of product towards customer satisfaction of Warung Apung Maritim food stall" is accepted.

3. The Influence of Service Quality towards Customer Satisfaction:

Service Quality variable partially has significant influence towards customer satisfaction. This can be known from its significance by 0.002 which means less than 0.05 . The results of this study prove that the service quality has positive or significant influence towards customer satisfaction, at which the increase of service quality will result in an increase of customer satisfaction. The result indicates that the hypothesis "Allegedly there is an influence of the quality of product towards customer satisfaction of Warung Apung Maritim food stalls in West Surabaya" is accepted.

4. The Influence of the Quality of Product, Facility, and Service Quality towards Customer Satisfaction:

The result of the analysis shows that independent variables comprising the Quality of Products (X1), Facilities (X2), Service Quality (X3) simultaneously has significant influence over the dependent variable, that is, Customer Satisfaction $(Y)$, since the value of $F$ count $>$ $\mathrm{F}$ table, i.e. $14.432>2.31$. This shows that the hypothesis "Allegedly there is an influence of the quality of product towards customer satisfaction of Warung Apung Maritim food stalls" is accepted. All independent variables have influence over the variation of dependent variable by $31.1 \%$. This is proven by looking at the value of coefficient of determination ( $R$ Squared) by 0.311 , whiles the remaining, $68.9 \%$, and is influenced by other factors outside the model. Figures of correlation coefficient (R) shows entanglement of relationship between independent variable of the quality of Product (X1), facilities (X2), Service Quality (X3) in a together with Consumer Satisfaction $(Y)$ shows a high value by 0.558 .

The dominant Influence of the quality of Product, Facility, Service Quality towards Customer Satisfaction. Based on the beta value, variable which has dominant influence on Customer Satisfaction is variable of the quality of product $(\mathrm{X} 1)$, because it has the biggest value by 0.162 rather than the variable of service quality (X3) and facilities (X2), thus the research hypothesis that reads "Allegedly there is an influence of the quality of product towards customer satisfaction of Warung Apung Maritim food stall", is accepted. 


\section{CONCLUSION AND SUGGESTIONS}

According to the result of discussion on "The Influence of the Quality of Product, Facility, Service Quality on Consumer Satisfaction (Case Study on Customer of Warung Apung Maritim food stall, West Surabaya)", so it can be concluded as follow:

1. The result of test validity shows that it has been valid, having been known that from all variables the value of significance is $<0.05$ and the value of coefficient correlation ( $r$ count) of each indicator from all independent or dependent variable is greater than $r$ table, so that it can be stated that all of variables of this research was valid.

2. The result of test reliability shows that each of variables has coefficient alpha which is more than 0.60 , so that it can be concluded that the data is reliable.

3. According to the calculation analysis of multiple linear regression, then it was got an equation like this:

$$
Y=3.835+0,162 \times 1+0,064 X 2+0,106 \times 3
$$

From that formula of regression it can be known that the greatest value of beta is in the variable of service quality by 0.162 . For that reason, variable of product quality has the most dominant influence towards customer satisfaction of Warung Apung Maritim, West Surabaya.

1. The result of coefficient of determination ( $R$ Squared) is 0.311 ; it shows that the proportion of product quality influence, facility, and service quality on customer satisfaction is $31.1 \%$. It means that of all variables, $X$ has influence proportion by $31.1 \%$ while the remaining, $68.9 \%$, is influenced by another variable that was not observed.

2. Analysis of the correlation coefficient of multiple linear results in a relationship between the quality of products, facilities, quality of service towards customer satisfaction, which the value of $R$ is 0.558 . It indicates that the proportion of the relationship between the qualities of products, facilities, service quality on customer satisfaction is very powerful and positive at $55.8 \%$. This means that the quality of products, facilities, service quality has proportions of relationship closeness to customer satisfaction by $55.8 \%$ while the remaining, $44.2 \%$, is influenced by other variables which is not examined.

3. The results of the partial test ( $t$ test) found that the variable quality of the product $(0.002)$, facilities $(0.001)$, and quality of service $(0.002)$ has significant influence over the customer satisfaction because the results of significance value are less than 0.05 .

4. While the results of simultaneous test ( $F$ test) found that the value of F-count is 14.432 , it greater than $F$ table by 2.31. In addition, significant value is $0.000<0.05$, thus $\mathrm{Ha}$ is accepted, it means that each variable of the quality of products, facilities, service quality simultaneously has significant influence over the variable of customer satisfaction.

Suggestion which can be made for Warung Apung Maritim food stall based on the conclusion above is that as a business entity which is engaged in a culinary business, things that need to do to make benefit for future research and develop its business is:

Keeping in mind that the quality of product has influence over the customer satisfaction in a dominant manner, thus management fraud of Warung Apung Maritim food stall, West Surabaya should consider improving the quality of service and facility owned to encourage customer satisfaction that in the end will help to improve the number of visitor;

To improve the customer satisfaction, it needs to offer value added. It causes customer feel that they get more than they pay or even more than they expect. To add value does mean to decrease price or give additional service, however it can simply does, such as improving the quality of dish, comfort and pace of service or by training employee so that able to answer the needs of customer instead of paying attention all of facilities needed by customers when they utilize service offered and finally able to satisfy customer. 


\section{REFERENCES}

1. Apriani, M. (2011). Analisis Pengaruh Fasilitas, Kualitas Pelayanan Dan Kepuasan Pelanggan Terhadap Minat Mereferensikan (Studi kasus pada konsumen jasa pelayanan cuci sepeda motor dan mobil Star Clean di Semarang). Unpublished Dissertation. Universitas Diponegoro Semarang.

2. Arief, Prof. Dr. (2007). Pemasaran Jasa dan Kualitas Pelayanan. Banyumedia Publising, Jakarta.

3. Arikunto, S. (2005). Manajeman Penelitian. Rineka Cipta, Jakarta.

4. Assauri, S. (2002). Manajemen Pemasaran (dalam konsep dan strategi). Rajawali Grafindo, Jakarta.

5. Bahtiar. (2009). Strategi dan Program Pemasaran. Penerbit Andi, Yogjakarta.

6. Fajar, L. (2008). Manajemen Pemasaran: Pendekatan Praktis. Graha Ilmu, Yogyakarta.

7. Ferdinand, A. (2006). Metode Penelitian Manajemen. $2^{\text {nd }}$ edition. UNDIP, Semarang.

8. Ghozali, I. (2006). Aplikasi Analisis Multivariate dengan SPSS. Badan Penerbit UNDIP, Semarang.

9. Ghozali, I. (2005). Aplikasi Analisis Multivariate dengan SPSS. Badan Penerbit UNDIP, Semarang.

10. Julita. (2001). Prinsip Kepuasan Pelanggan. Elek Media Komputindo, Jakarta.

11. Kotler, P. (1996). Manajemen Pemasaran. Erlangga, Jakarta.

12. Kotler, P., Armstrong, G. (2001). Dasar-dasar Pemasaran. PT. Indeks. Kelompok Gramedia, Jakarta.

13. Kotler, P. (2005). Manajemen Pemasaran. $2^{\text {nd }}$ edition. Indeks, Jakarta.

14. Lamb, H.M. (2001). Pemasaran. Salemba Empat, Jakarta.

15. Lupiyoadi, R. (2001). Manajemen Pemasaran Jasa: Teori dan Praktik. $1^{\text {st }}$ edition. Salemba Empat, Jakarta.

16. Lupiyoadi, H. (2006). Manajemen Pemasaran Jasa. $2^{\text {nd }}$ edition. Penerbit Salemba Empat, Jakarta.

17. Mursid, D.M. (2008). Manajemen Pemasaran. PT. Bumi Aksara, Jakarta.

18. Moenir. (1995). Manajemen Pelayanan Umum di Indonesia. Bumi Aksara, Bandung.

19. Sugiyono. (2009). Metode Penelitian Kuantitatif Kualitatif dan RandD. Alfabeta, Bandung.

20. Sugiyono. (2010). Metode Penelitian Kuantitatif Kualitatif dan RandD. Alfabeta, Bandung.

21. Swastha, B., Handoko, T.H. (2000). Manajemen Pemasaran Analisa Perilaku Konsumen. $6^{\text {th }}$ edition. BPFE, Jakarta Barat.

22. Tjiptono, F. (2004). Pemasaran Jasa. Bayumedia, Malang.

23. Wahjono, S.I. (2009). Manajemen Pemasaran Bank. Graha Ilmu, Surabaya.

24. Wijaya, Puspo, L.R., Bandi, Wibawa, A. (2010). Pengaruh Keputusan Investasi, Keputusan Pendanaan dan Kebijakan Deviden Terhadap Nilai Perusahaan. Simposium Nasional Akuntansi XIII, Purwokerto.

25. Wisnalmawati. (2005). Pemasaran: Prinsip dan Kasus. BPFE, Yogyakarta. 